\title{
The Environmental Compliance Management of Palm Oil Plantation in Ogan Komering Ilir Regency, Sumatera Selatan, Indonesia
}

\author{
M. Yusuf ${ }^{1, *}$, Yusnizal Firdaus ${ }^{1}$, Markoni Badri ${ }^{1}$, Al Husori $^{1}$ \\ ${ }^{I}$ Department of Business Administration, State Polytechnic of Sriwijaya, Palembang, Indonesia \\ Corrresponding author.Email: habib_yosefa9@yahoo.com
}

\begin{abstract}
This research is determined to know the palm oil factory controlling that have done by the Ogan Komering Ilir Regency enviromental agency. It is can be worried about the violation of compliance with regulations resulted the environmental damage. There are 10 palm oil companies in Ogan Komering Ilir Regency. This research is focus to the company's compliance to the company's activities in reporting the environmental management and the performance of environmental supervisors at Ogan Komering Ilir Environmental Regency Office. This research uses qualitative analyzing by using the interview techniques. The research prove that (1) Preliminary supervision conducted by the supervisory staff of Ogan Komering Ilir Regency Environmental Office requires supervision techniques that are truly in accordance with the rules of environmental protection and management. (2) Supervision of the implementation of compliance by company administration in carrying out the environmental management is generally still low, as indicated by the fact that there are still a few companies that submit the Semester Reports on Environmental Management Efforts and Environmental Monitoring Efforts there are still many complaints from the public regarding allegations of pollution or environmental damage as a result of the business / activity. (3) The feedback of supervision in the process resulted a lack of company compliance in reporting liquid waste management due to the absence of a guidebook that can be used as a basic implementation in a district/city government supervision to increase industrial compliance in environmental management. The industrial polution cases that curently happened is the waste water seeping from one of the palm company in Lubuk Ketepeng village, Jejawi. Based on the accident, it expected to increase the human resources, additional budget to operate the controling in the place. The released of guide book about report of enviromental management to company enviroment and the penalty for those causes the polution.
\end{abstract}

Keywords: controlling, compliance, environment

\section{INTRODUCTION}

Palm is one of the best export Indonesian comodity and frequently increase until 9.92 percent per year and become the biggest palm oil producer in the world. Indonesia has 8,04 million hectares and produce the oil 19,76 million tons in a year [1]. Based on [2] the producing activities from the bunches fresch fruit (BFF) to crude palm oil (CPO) resulted waste that can be processed to make biogas or bioreactors as a methane gas source. One ton of waste has a potential to produce $3,136 \mathrm{~m} 3$ or around 6,530 tons of biogas which can be used for LPG. he rest from the waste can be used for feed ingredients. Naibaho [3] states that palm oil in addition to producing liquid waste, in the production and processing of FFB also produces solid waste in the form of empty bunches, fibers and shells. Palm oil can be classified as a friendly environmental plant, because it is contribute absorbing carbon greenhouse gas emissions and in the liquid waste and solid waste production process can be used to substitute low-energy and prevent environmental pollution. A hectare of Palm oilplantation can absorb 24.64 tons carbon of $\mathrm{CO} 2$ per year. A ton of FFB can produce 3,136 $\mathrm{m} 3$, equivalent to 6,530 tons of LPG. Solid waste from FFB produced from empty bunches (TK) can be processed into 600 to $650 \mathrm{~kg}$ of compost, and hydrolyzed can produce about 120 liters of bioethanol. It obvious that palm oil plants have a huge role and their derivative products as sustainable economies that can increase the economy income. South Sumatera is one of the largest palm oil producers in Indonesia with the huge of palm oil plants that reach 866,763 hectares with a fresh fruit brunches total production around 2.11 million tons [4]. there is the composition of palm oil plantations in South Sumatra, 55.14 percent is cultivated by plantations owned by the company, 29.52 percent is cultivated by farmers who are members of the Palm Oil Plantation Plasma Program, and 15.34 percent is freely cultivated by the people. In South Sumatra, palm oil mill effluent (POME) has been processed into a 4 megawatt capacity power plant located in Ogan Komering Ilir 
Regency. Utilization of palm oil wastes through the Biogas Power Plant is a solution for areas that until now have not had sufficient access to regional energy of electricity [5]. However, the development of the Palm Oil industry in Ogan Komering Ilir Regency also has encouraged the development of the other businesses that support it is also bring support against increasing environmental pollution around the certain area, in this case, the Environmental Compliance of Life in the Palm Oil Industrial Area in Ogan Ilir Komering. Regency environmental oversight is an activity carried out directly or indirectly by the Environmental Services supervisory apparatus to find out and guarantee the compliance of the person who responsible for a business and/or activity regarding to regulations in controlling the environmental pollution. In carrying out supervision, supervisors are required to learn the industry monitoring and environmental management regulations related to it. Therefore, supervisors need good and correct supervision techniques that are in accordance with the rules of environmental protection and management.

\section{LITERATURE REVIEW AND HYPOTHESIS DEVELOPMENT}

\subsection{Controlling}

The supervision [6] determining what has been done, in order to evaluating work performance and, if it necessary, implementing corrective actions so that work results are in accurate with the established plans. Robbin [7] states that supervision is a very basic activity process, that requires a manager to carry out the tasks and work of the organization. According to [8], in essence, supervision is a whole rather than an activity that compares or measures what is or has been carried out with the criteria, norms, standards or plans that have been determined previously.

Siagian (2010) [9] states that what is meant by supervision is a process of observation rather than the implementation of all activities of the organization to ensure that all work being carried out goes according to a predetermined plan.

Based on the opinion of the experts above, it can be conclude that supervision is a systematic effort to set a standard implementation of objectives with objectives planning, design a feedback information system, comparing real activities with predetermined standards, determine and measure deviations and required to take corrective actions. With All of that the supervision in management, the expected planning by management can be fulfilled and run well. Without supervision from the manager / supervisor, the plan that has been determined will be difficult to imply properly by subordinates. So the goals that company expected can be difficult to be realize.

According to [9], supervision will run effectively if: !)onitoring must reflect what the various nature activities carried out; 2) Oversight must immediately provided guidance on the possible deviations from theplan; 3)
Oversight must determine exceptions at certain strategic points; 4) Objectivity in conducting surveillance; 5) Supervision's flexibility 6) Supervision must change the basic pattern of the organization; 7) Efficiency of supervision implementation; 8) Understanding of the supervision system by all parties involved; 9) Oversight looks for what has gone wrong; 10) Supervision must be active in guiding.

Siswandi [10] said that the objectives of supervision are: 1) Measuring compliance with policies, plans, procedures, regulations and applicable laws; 2) Maintain organizational resources; 3) Achieve the goals and objectives set by the organization; 4) The trusted information and the integration of information in the organization; 5) The ongoing performance and then compare the actual performance with the standard and establish the degree of deviation which one looks for the right solution.

Siagian [9] revealed that the supervision process is basically carried out by administration and management by using two kinds of techniques, namely: 1) Direct supervision (direct control); 2) Indirect supervision (indirect control)

There are three basic types of supervision according to [11], there are: 1) Preliminary Supervision. This monitoring is designed to anticipate problems or deviations from the standards or objectives and allow corrections to be made before a certain stage of activity is completed. This supervision will be more effective if the manager is able to get the accurate information about changes in the environment or about the development of desired goals; 2) Concurrent" supervision. This supervision, often called "Yes - No" supervision, scerrening control or "stop - continue", is carried out during an activity. This type of supervision is a process in which certain aspects of a procedure must be approved first, or in certain conditions must be done before activities can proceed; 3) Feedback control. This monitoring measures the results of an activity that has been completed.The causes for deviations from the plan or standard are determined, and the inventions should be set for the similar activities in the future This supervision is historical, measurements are made after the activity occurs.

The supervision process according to [11] consists of five stages, The stages are:

Stage 1: Standard Setting

The first stage in supervision is the setting of implementation standards. Standard implies as a unit of measurement that can be used as a "benchmark" for evaluating results The goals, objectives, quotas and targets implementation can be used as a standard.

Stage 2: Determination of Measurement of Activity Implementation Determine the measurement of the implementation of activities correctly and evaluate the performance achieved against predetermined standards.

Stage 3:Activity Measurement Implementation

After the measurement frequency and monitoring system are determined, the implementation measurement is carried out as an iterative and continuous process. There are various ways to measure implementation, namely: 1) Observation; 2) Reports, both oral and written; 3) Automatic methods; 4) Inspection, testing, or by taking samples. 
Stage 4: Comparison of Implementation with Standards and Analysis of Deviations

The critical stage of the monitoring process is the comparison of actual implementation with planned implementation or established standards. Although this stage is the easiest to do, complexity can occur when interpreting deviations. Deviations must be analyzed to determining why standards cannot be achieved. Decision making shows how important it is to identify the causes of the deviation.

Stage 5: Take Corrective Actions When Necessary If the results of the analysis indicate the need for corrective action, this action must be taken. Corrective actions can be taken in various forms. Standards might be changed, implementations improved, or both done together. Corrective action might be: 1) Changing the initial standards (perhaps too high or too low); 2) Changing measurements measurement of implementation (inspection too often the frequency or lack or even replace the measurement system itself) ; 3) Changing the way in analyzing and interpreting deviations.

\subsection{Environmental Management}

According to Law Number 32 of 2009 concerning Environmental Protection and Management, the definition of environmental protection and management is a systematic and integrated effort undertaken to preserve environmental functions and prevent environmental pollution and/or damage which includes planning, utilization, control, maintenance, supervision and law enforcement. [5] stated: "Environmental management is an integrated effort to preserve the function of the environment which include the policies of structuring, exploiting, developing, maintaining, restoring supervision, and controlling the environment".

Environmental management carried out with the principles of state responsibility, the principle of sustainability and the principle of benefits aims to realize sustainable development that is environmentally sound in the context of the development of Indonesian people as a whole and the development of Indonesian society as a whole and has faith in God and the Almighty. The targets of environmental management are [12] Achieving harmony, the balance relation between humans and the environment; 2) The realization of Indonesian people as environmental insane who have attitudes and actions to protect and foster the environment; 3) Guaranteed interests of the present and future generations; 4) The achievement of environmental function preservation; 5) Control of the wise use of resources; 6) Protection of the Unitary State of the Republic of Indonesia from the impacts of businesses and/or activities outside the territory of the State that cause environmental pollution and / or damage.

Environmental management is not just the responsibility of the government. The private sector and the community also play a very important role in implementing environmental management policies. The rule of law as a well-established concept includes the tools of the State apparatus, especially the tools of the government which, in its actions, both for pre-citizens and in relation to other State institutions, must not be arbitrary, but must be pay attention to regulations applicable legal regulations. Likewise to member community, in social relations must also comply with applicable legal regulations. Every person has the right and obligation to participate in the framework of environmental management, so that the preservation of environmental functions can be achieved. Preservation of environmental functions is a series of efforts to maintain the sustainability of the carrying capacity and carrying capacity of the environment. Carrying capacity is the ability of the environment to support human life and other living things, while the capacity of the environment is the ability of the living environment to absorb substances, energy, and / or other components that enter or enter into it.

The effort to protect environment are based on environmental quality standards, both in the form of environmental quality criteria (ambient) and the quality of waste or effluent. Environmental quality standard is a measure of the limit or level of living things, substances, energies, or components that exist or must be present and / or pollutant elements that are held in a certain resource as environmental elements. Quality standards as benchmarks determined whether the environment has been damaged or whether an activity has damaged the environment need to be carried out and referred to national development activities. Environmental quality standards can be different for particullar regions or times, given the differences in environmental conditions, and spaces for planning and technology. Management of the environment and natural resources is a main problem in the sustainability of development and the national economy. The environmental crisis and the destruction of natural resources are common phenomena from development

\subsection{Environmental Policy in Indonesia}

According to Indonesian Law policy Number 32 of 2009 concerning Environmental Protection and Management, the definition of environmental protection and management is a systematic and integrated effort undertaken to preserve environmental functions and prevent environmental pollution and/or damage which includes planning, utilization, control, maintenance, supervision and law enforcement.

According to [5] environmental management is an integrated effort to preserve the function of the environment which includes the policies of structuring, exploiting, developing, maintaining, restoring supervision, and controlling the environment". Environmental management carried out the principles of state responsibility, the principle of sustainability and the principle of benefits aims to realize sustainable development that is friendly environmental in the context of the development of Indonesian as a whole and the development of the Indonesian who are all faithful and devoted to God Almighty. The targets of environmental management are: 1) Achieving harmony, harmony and balance between humans and the environment;2) The 
realization of Indonesian people as environmental insane who have attitudes and actions to protect and foster the environment ; 3) Guaranteed interests of the present and future generations; 4) The achievement of environmental function preservation; 5) Control of the wise use of resources; 6) Protection of the Unitary State of the Republic of Indonesia from the impacts of businesses and / or activities outside the territory of the State that cause environmental pollution and / or damage.

Environmental Management is not just an eye to be the responsibility of the government. Private sector and society are also very important. The rule of law includes the concept which includes state equipment, especially the tools of the government which, in its actions, both to citizens and in supporting with other countries, cannot be arbitrary, regulations need to be considered applicable law. Likewise with community members, community relations must also comply with applicable regulations. Everyone has the right and commitment to manage the environment, so that they can manage environmental sustainability. Environmental preservation is conservation of the carrying capacity and carrying capacity of the environment. Carrying capacity is the environment to support human life and other life planning, while the carrying capacity of the environment is the ability of the environment to connect substances, energy, and/or other components that enter or enter into relationships.

Efforts to protect the environment are based on environmental quality standards, both in the form of environmental quality criteria (ambient) and the quality of waste or effluent. Environmental quality standard is a measure of the limits or levels of living things, substances, energy, or components that exist or must be present and / or pollutant elements that are held in a certain resource as environmental elements. Quality standards as benchmarks to determine whether the environment has been damaged or whether an activity has damaged the environment needs to be carried out and referred to in national development activities. Environmental quality standards can be different for different regions or times given the differences in environmental conditions, spatial planning and technology. Management of the environment and natural resources is a fundamental problem in the sustainability of development and the national economy. The environmental crisis and the destruction of natural resources are common phenomena of development.

\subsection{Conceptual framework}

The Minister of Environment Regulation No. 56/2002 concerning General Guidelines for Supervision of Environmental Compliance for Supervisory Officers states that the purpose of environmental supervision is to monitor, evaluate, and determine the status of compliance with business and / or activities responsible for: 1) Obligations contained in legislation in the field of pollution control and or environmental damage;; 2) Obligations to carry out environmental management and environmental monitoring as stated in the Environmental Impact Assessment (EIA) or Environmental Management Efforts (EME) and Environmental Monitoring Efforts or environmental requirements stated (ERS) in the relevant permits; 3) This supervision activity is needed so that the person in charge of the activities obeys all environmental laws and regulations, requirements in various licenses (business licenses, waste disposal permits, etc.) as well as requirements regarding all environmental media (water, air, soil, noise, vibration) that should be listed in the licensing that has been owned. This handbook can be used as a basis for implementing district/city government oversight to improve industry compliance in environmental management.

\section{RESEARCH METHODOLOGY}

The object of this research is oil palm plantations located in Ogan Komering Ilir Regency (OKI), South Sumatra Province, Indonesia. The number of companies engaged in oil palm plantations in Ogan Komering Ilir Regency is 10 companies. The focus of this research is on the company's compliance with company activities in reporting on environmental management and the performance of environmental supervisors at the Ogan Komering Ilir District Environmental Office. The analysis in this research is to use qualitative analysis with an interview technique approach. As an indicator of variables in this research follows: 1) Preliminary Supervision (SDM Superintendent Determination of the objectives and provisions of supervision, Supervisory Budget, The Supervisor Work Program, Compilation of a Monitoring Plan); 2) Implementation Oversigh (Supervision and control of costs, Quality control and supervision, Control of time); 3) Feedback Monitoring (Work Scheduling and Workforce Control; Job Report Informants in this research are: 1) Head of the Environment Pollution and Damage Control Division; 2) Head of Compliance and Environmental Capacity Building; 3) Environmental Monitoring Jobs; 4) Field Officer in Environmental Damage Control; 5) The leadership of a palm oil company at OKI; 6) The community around the company.

\section{RESULTS AND DISCUSSION}

\subsection{Preliminary Supervision}

\subsubsection{Human Resources Supervisor}

The human resources in this research are Supervisors namely Ogan Komering Ilir environmental service employees who have been trusted by the Ogan Komering Ilir Government based on Ogan Komering Ilir Regulation Number 2 of 2016 concerning Formation and Composition of Ogan Komering Ilir Regional Gazette of Ogan Komering Ilir Year 2016 Number 2). In carrying out supervision, 
supervisors are required to study the industry to be monitored and environmental management regulations related to it. Therefore, supervisors need good and correct supervision techniques that are in accordance with the rules of environmental protection and management. In this case the supervisors owned by the OKI Regency Environmental Agency still have not mastered in detail.

\subsubsection{Determination of the Purpose and Scope of Supervision.}

in the terms of reference in the technical proposal document, the determination of the objectives carried out according to the type of activity carried out in this case the purpose of supervision is to assist the Environmental Agency of Ogan Komering Ilir in Supervision of Environmental Compliance in the Palm Oil Plantation Area in Ogan Komering Ilir. The purpose of environmental monitoring is to monitor, evaluate and determine the status of compliance with business and / or party responsible for: 1) Obligations containing legislation in the field of pollution control and or environmental damage; Obligations to carry out environmental management and environmental monitoring; 2) As stated in the Environmental Impact Assessment document or Environmental Management Efforts and Environmental Monitoring Efforts or environmental requirements stated in the relevant permits Monitoring Budget; 3) The oversight budget is sourced from the Ogan Komering Ilir Regional Revenue Budget South Sumatra. However, the budget for Supervision of Environmental Compliance in the Palm Oil Mill Area in Ogan Komering Ilir is felt to be inadequate where there are still limited operational funds for the needs of direct field supervision carried out given the large number of jobs encountered in the field such as there are still several Palm Oil companies in Ogan Komering Regency Ilir Obviously heavy enough to carry out direct supervision with a very small number of apparatus. Where supervision is an activity to find, correct deviations in implementation and the results achieved from planned activities.

\subsubsection{Supervisor Work Program}

Before the supervisor carries out supervision, of course the Environmental Compliance Oversight must first prepare the Supervisory Work Program. Arranging the work program, allocation of personnel and the conception / methodology of the implementation of supervisory work is a preparation that must be carried out by the Supervision of Environmental Compliance. In carrying out supervision, of course the Environmental Oversight Supervision must prepare a work program to be carried out in the implementation of the Environmental Oversight Supervision in the Palm Oil Mill Area in Ogan Komering Ilir. The work program created must be based on the Terms of Reference in the development being carried out.
These are following description of the supervisor's work program, including: a) Preparation Stage; b) Activity Planning Stage; c) Reporting Phase

\subsubsection{Preparation of a Monitoring Plan}

The results of the study note that the preparation of the supervision plan has been carried out well following the procedures and also adjusted the Terms of Reference/work for the implementation of Environmental Compliance Monitoring in the palm oil industry in Ogan Komering Ilir . Whereas the preparation of the Supervision Team includes the first stage in the preparation of the implementation of Environmental Compliance in the Oil Palm Factory Area in Ogan Komering Ilir, which is conducting the preparation of an Environmental Management Implementation Team in the Oil Palm Factory Area in Ogan Komering Ilir .

The result of this research note that the preparations of the supervision plan has been carried out well following the procedures and also adjusted the Terms of Reference / work for the implementation of Environmental Compliance Monitoring in the palm oil industry in Ogan Komering Ilir. Whereas the preparation of the Supervision Team includes the first stage in the preparation of the implementation of Environmental Compliance in the Palm Oil Factory Area in Ogan Komering Ilir, which is conducting the preparation of an Environmental Management Implementation Team in the Palm Oil Factory Area in Ogan Komering Ilir Regency.

\subsection{Supervision}

\subsubsection{Standard Setting}

Supervision is carried out not only to record and provide criteria for the company's compliance index but furthermore the Department of the Environment gives awards to companies that join to management in the form of gold flags While companies that do not comply with regulations in the management of industrial waste are given administrative sanctions up to the suspension of licenses and criminal sanctions.

\subsubsection{Determination of measurement of activity implementation}

Supervision of Environmental Compliance in the Palm Oil Mill Area the goal to be achieved is the creation of a good environment and management of industrial waste in accordance with laws and regulations. For this reason, during the supervision carried out by the Office of the Environment there is a conclusion of the results of the supervision which is known jointly between the company and employees of the Office of the Environment. Where the results obtained in the field on average recommend improvement improvements so that industrial waste can be 
minimized the impact of pollution. The Office of the Environment in addition to visiting, making direct observations to the location of industrial waste, but also indirectly supervising by requesting the results of measurements of liquid waste quality standards, laboratory test results, and so forth that must be submitted by the company to DLH every period of 6 months.

\subsubsection{Measurement of implementation of activities}

After the measurement frequency and monitoring system are determined, the implementation measurement is carried out as an iterative and continuous process. There are various ways to measure implementation, namely: 1) Observation; 2) Reports, both oral and written; 3) Automatic methods; 4) Inspection, testing, or by taking samples.

Many companies now use internal auditors as measurement implementers.

Referring to this research, the writer tries to find out the obstacles faced by the Department of Environment in the process of carrying out supervision activities. Whereas the obstacle in carrying out the supervisory function faced by the Ogan Komering Ilir Environmental Office lies in internal factors (lack of personnel, supporting facilities and infrastructure) and external factors, namely the limited number of companies and waste testing laboratories.

\subsubsection{Comparison of implementation with standards and analysis of deviations}

In the supervision it is known why there are problems by the company related to the lack of company compliance in managing the environment in Ogan Komering Ilir because there is no manual that can be used as a basis for the implementation of district/city government supervision to increase industrial compliance in environmental management.

\subsubsection{Taking Corrective Action}

When needed In this study, irregularities committed by the company cause compliance in providing reports on the implementation of the Environmental Management Plan and the Environmental Monitoring Plan.

The author tries to describe who discusses obedience by supervisors, among others: 1) The company has an Environmental Permit; 2) The company has a Environmental Protection and Management Permit (PPLH) such as an Integrated Waste Management Permit or Liquid Waste Utilization Permit for land, Temporary B3 Waste Storage Permit, and Domestic Waste Water Management Permit; 3) Management of liquid waste in accordance with applicable regulations namely LH Regulation No. 1 of 2010 concerning the procedures for regulating air pollution; 4) Management of B3 waste in accordance with applicable regulations, namely Government Regulation No. 101 of 2014 concerning Management of B3 Waste; 5) Domestic Water Management in accordance with applicable regulations, namely Permen No. P.68 concerning Quality Standards for Domestic Waste; 6) Carry out management and implementation for air, air and soil quality parameters according to the Environmental Impact Analysis document; 7) Carry out waste management from solid waste according to Government Regulation No. 81 of 2012.

\subsection{Feedback monitoring (after implementation)}

\subsubsection{Work scheduling and labor control}

Joint surveillance actions will have a very effective effect in monitoring industrial waste which will result in environmental pollution. Where joint supervision can be done by providing an opportunity for the entire community to convey information if there are findings that are suspected of environmental pollution due to industrial waste. While from the company itself, it should regularly and continuously check the industrial waste produced.

\subsubsection{Supervision Reports}

As the supervisor's obligation to provide tangible results in accordance with the required specifications, the supervisor will monitor all work results achieved and provide a written report to the Regent / Deputy Regent. The form of the report given is a report on the results of the supervision of environmental management which is completed with minutes of supervision in the field.

\section{CONCLUSIONS}

Preliminary supervision conducted by the supervisory staff of the OKI Regency Environmental Agency requires good and correct supervision techniques in accordance with the principles of environmental protection and management.

Supervision of the implementation of compliance and compliance with company administration in carrying out environmental management is generally still low, as indicated by the fact that there are still very few companies that submit Semester Reports on Environmental Management Efforts and Environmental Monitoring Efforts and there are still many complaints from the public regarding allegations of pollution or environmental damage as as a result of the business / activity.

Supervision of feedback in the supervision process in which there is a lack of company compliance in reporting liquid waste management due to the absence of a guidebook that can be used as a basis in the implementation of district/city government supervision to increase industrial compliance in environmental management. Recent cases of pollution and 
environmental damage from the industrial sector such as environmental pollution in Lubuk Ketepeng Village, Jejawi due to waste water seeping from one of the palm oil companies.

Based on these inventions, it is expected to increase the ability of human resources, additional budget for operational needs of supervisors in the field. issuance of manuals on environmental management reporting for companies and the imposition of strict sanctions on environmental pollution.

\section{ACKNOWLEDGMENTS}

This research is based on work supported by State Polytechnic of Sriwijaya, Indonesia. The author thankfully acknowledges scientific discussion with our colleagues from State Polytechnic of Sriwijaya, Indonesia. The authors would like to acknowledge the anonymous reviewers at the IC FIRST 2019 for their feedback on an earlier version of the paper, and also thank to the two anonymous reviewers who provided feedback as part of this journal's review process.

\section{REFERENCES}

[1] Direktorat Jenderal Perkebunan, Laporan Tahunan 2014, Ditjenbun, Jakarta, 2014.

[2] Djajadiningrat ST dan Famiola, Kawasan Industri Berwawasan Lingkungan, Penerbit Rekayasa Sains, Bandung, 2004.

[3] Naibaho PM, Teknologi Pengolahan Kelapa Sawit, Pusat Penelitian Kelapa Sawit, Medan, 1996

[4] Dinas Perkebunan Sumatera Selatan, Sumatera Selatan dalam Angka, Dinas Perkebunan Sumatera Selatan, Palembang, 2016

[5] Ferial, PLTG Berkapasitas 4 MW Beroperasi di Sumatera Selatan, Sumatera Ekspres, 17 Desember 2015.

[6] Terry, G.R. 2011. Prinsip-Prinsip Manajemen, Jakarta: Bumi Aksara

[7] Robbins, Stephen \& Mary Caulter. 2016. Manajemen, Jilid I Edisi 13. Jakarta: Erlangga.

[8] Siagian, Sondang P. 2008. Pengantar Manajemen. Jakarta: Bumi Aksara.

[9] White, Colin. 2014. Strategic Management. Palgrave Macmillan

[10] Siswandi dan Indra Iman. 2009. Aplikasi Manajemen Perusahaan. Jakarta: Mitra Wicana Media.
[11] Handoko, T.Hani. 2012. Pengantar Manajemen. Jakarta: Rineka Cipta..

[12] Andi, Ansyori. 2013. Manajemen Personalia dan dan sumberdaya manusia. Yogyakarta: BPFE. 